\title{
EFFECT OF RELIGIOSITY, PREVENTION FOCUS, FUTURE ORIENTATION, AND FINANCIAL KNOWLEDGE ON PURCHASE INTENTION TO LONG-TERM INVESTMENT IN SHARIA INSURANCE
}

\author{
Kusumajati Wahyu*, Syah Tantri Yanuar Rahmat, Kustiawan Unggul, \\ Negoro Dimas Angga, Tegor \\ Faculty of Economics and Business, Esa Unggul University \& STIE Cakrawala Karimun, \\ Indonesia \\ *E-mail: wahyu weka@yahoo.com
}

\begin{abstract}
This research aims to examine the effect of religiosity on purchase intention to long-term investment in sharia insurance which is moderated by prevention focus, future orientation, and financial knowledge. This research applies a non-hierarchical analysis method or cell mean method using between subject $2 \times 2$ and the procedure of Univariate General Linear (GLM) Model. The first research finding found that religiosity has significantly affected purchase intention to long-term investment in sharia insurance; thus, $\mathrm{H} 1$ has supported the hypothesis. The second finding showed that high religiosity which is moderated by low prevention focus increases purchase intention to long-term investment in sharia insurance; thus, $\mathrm{H} 2 \mathrm{a}$ has supported the hypothesis. However, religiosity which is moderated by high prevention focus does not support the hypothesis, thus, $\mathrm{H} 2 \mathrm{~b}$ and $\mathrm{H} 2 \mathrm{c}$ are not proven. The third finding found that religiosity which is moderated by future orientation has shown very significant result, thus, the $\mathrm{H} 3 \mathrm{a}, \mathrm{H} 3 \mathrm{~b}$, and $\mathrm{H} 3 \mathrm{c}$ hypotheses have been proven to support the hypothesis. The fourth findings showed that high religiosity which is moderated by low financial knowledge has been proven to affect purchase intention to long-term investment in sharia insurance; so, $\mathrm{H} 4 \mathrm{a}$ has supported the hypothesis. However, religiosity which is moderated by high financial knowledge has not supported the hypothesis; thus, $\mathrm{H} 4 \mathrm{~b}$ and $\mathrm{H} 4 \mathrm{C}$ is not proven.
\end{abstract}

\section{KEY WORDS}

Religiosity, prevention focus, future orientation, financial knowledge, purchase intention.

Nowadays, the world of Indonesian insurance faces considerable challenges with the presence of many foreign insurance companies as a direct impact of globalization. In addition, in this globalization era, Indonesian insurance and reinsurance companies will face the presence of foreign insurance or reinsurance companies that have strong capital and reliable technology and human resources. In addition, they also have the opportunity to operate and develop the insurance or reinsurance business in other countries besides Indonesia (Ramadhani, 2015). In dealing with the current of globalization, the positive thing that we can examine is that there is healthy competition which will gradually make the development of sharia insurance increase globally. More and more Islamic banks are implementing sharia principles; i.e. the banking system that does not lend or collect loans with interest loans (usury) and has a prohibition to invest in illegitimate businesses according to Islamic teachings. The Financial Services Authority (OJK) has recorded data of April 2017 which stated that the market share of sharia insurance in Indonesia is still very low; i.e. $3.45 \%$ of the total compulsory insurance and social insurance. National sharia insurance assets reached IDR 34.3 trillion. Meanwhile, conventional insurance assets reached IDR 958.06 trillion. Then, the combined total assets reached IDR 992.34 trillion. Based on previous OJK data, the authors found the instability of the market share of sharia insurance in Indonesia, which declined compared to total assets in 2014 of $4.5 \%$ and 2015 of $5.2 \%$.

According to data from the World Bank Global Islamic Finance Development Center in 2016 presented in Chart 1.1, Indonesia is in the 10th position with total assets of $1.6 \%$. Meanwhile, first, second and third positions are Iran 37.3\%, Saudi Arabia 19\%, and Malaysia 
9.3\%. Based on the above information from Table 1.1, Table 1.2, and Chart 1.1, we can see the gap between the Muslim population in Indonesia and the total ranking of sharia economic assets. Indonesia, with the largest Muslim population in the world, is only ranked 10th in total assets. Meanwhile, Iran, with a total Muslim population of one third of Indonesia, ranks first in the world for its total Islamic assets.

Based on the results of a national survey on financial literacy from OJK, in the 2013 period, concerning Indonesia National Strategy for Financial Literacy, the Insurance Literacy Index shows that well-educated Indonesians only accounted for $17.84 \%$ of the population in the insurance industry. It means that for every 100 people, there are only 18 people understand about insurance. Low insurance literacy rates contribute to low insurance products and services, which are only $11.81 \%$. This means that in every 100 people, there are only 12 people use insurance products and services. The low level of insurance literacy has become a challenge for financial and banking business actors in regulating their marketing strategies.

Based on a research conducted by Newaz et al. (2016) entitled "Muslim Religiosity and Purchase Intention of Different Categories of Islamic Financial Products" it was found that it is positively affected purchase attitude and intention in Islamic financial products. Regarding the product category, religiosity has a positive and significant effect on purchase intention to deposit products, credit and the Islamic capital market. On the contrary, religiosity has no significant effect on purchase intention to sharia insurance. Research conducted by Howlett et al (2008) has examined the role of self-regulation, future orientation and financial knowledge on long-term financial decision. Long-term financial decision, in this case, relates to the investment decisions of financial products by comparing investment with high-risk mutual funds and pension funds or what so-called Old Age Allowances in Indonesia and known as pension investment K401known in America. The findings of their research generally are that self-regulation, future orientation and financial knowledge significantly support their hypotheses and prove that low self-regulation will reduce intention to contribute to pension funds. However, that is contrary to the findings of mutual funds in which low selfregulation increases purchase intention to mutual funds.

Based on the authors' explanation above, there are two phenomena that underlie this research. The first is the demographic background related to the gap between the Muslim population in Indonesia which is not in line with the growth of sharia insurance and the OJK survey of financial literacy levels that are considered to be not optimally in line with the development of sharia insurance. The second phenomenon is the gap of the two previous research articles which shows that the level of religiosity does not support purchase intention to sharia insurance and the role of low self-regulation has supported long-term mutual fund investment decisions. From the two main phenomena described above, the authors intend to examine the effect of the religiosity variable which is moderated by the prevention focus and future orientation variables on purchase intention variable with the title "effect of religiosity, prevention focus, future orientation, and financial knowledge on purchase intention to longterm investment in sharia insurance.

In this research, the authors find the gap from the two main articles used as the basis for this thesis. The gap from the first article written by Newaz et al (2016) is about the correlation of religiosity which is moderated by purchase attitude which has a positive effect on the purchase intention of different categories of Islamic financial products. Their research gap stated that religiosity has not supported sharia insurance decision making. The second gap is based on the Howlett et al (2008) article which found that low self-regulation has been proven to affect customers in supporting retirement funds. However, low self-regulation does not affect the increase in mutual fund investment. Their findings cannot prove their hypothesis that low self-regulation will increase mutual fund investment. Based on the two gaps of the article, the authors want to examine the effect of religiosity on purchase intention to sharia insurance in particular and at the same time use the prevention focus, future orientation and financial knowledge variables as the moderation of the religiosity variable.

Based on the description in the background, this research aims to get explanation that can answer the following matters: (1) the effect of religiosity on purchase intention to long- 
term investment in sharia insurance and (2) that religiosity variable moderated by prevention focus, future orientation, and financial knowledge will increase purchase intention to longterm investment in sharia insurance.

\section{METHODS OF RESEARCH}

The research design applies descriptive qualitative method; i.e. a research that gives a careful description of a particular individual or group of conditions and symptoms (Koentjaraningrat, 1993). This research applies a relevant statistical model that will be presented as a cell formed or formed based on a particular characteristic based on sample data and the population under review (Sukmadinata, 2007). The advantage of analyzing the cell means model is that it is easily done manually and has a standard form. Therefore, it is easy to apply to all fields of study. The simplest and most easily understood cell model is a tabulation that is also called a cell means table. Descriptively, the cell means table presents the average value or mean score of the response variable, the non-independent variable or the causal variable (endogenous, dependent or downstream variables) that is numeric in scale. It includes the Likert scale according to several causal factors or independent variables (exogenous, independent or source variables) that are nominal or ordinal (Gunawan, 2013).

The analytical method used to test the research hypotheses is the cell means method. Data analysis basically aims to study the difference in mean response variables or indicators of certain problems between groups of individuals including in testing hypotheses about these differences in the population under review. Cell means functions have reciprocal correlation with cell means tables; i.e. a table that presents the means (average) nonindependent variable or indicator of a particular problem according to a factor or multifactor (Nugraha, 2014).

This cell means test applies the General Linear Model (GLM) procedure to test the null hypothesis that some groups of data samples have the same value or mean score. The application of the General Linear Model (GLM) Univariate procedure aims to test hypotheses about: 1) the characteristics of homogeneity; 2) differences or similarities of all mean parameters under review; 3) differences in several pairs of mean cell parameters; 4) the effect of the main factors and interaction factors on response variables, especially those that cannot be tested by applying the One-Way ANOVA procedure (Pramesti, 2007). It is necessary for General Linear Model (GLM) procedure of Univariate, by using statistical software, to analyze the General Linear Model Univariate, then enter the dependent variable and fix factor which is the coding of the religiosity, prevention focus, future orientation, financial knowledge, and purchase intention variables. Then, it is processed in a parameter estimate in statistical calculations.

The non-hierarchical ANOVA model can be written as follows: a model that contains the main factor $A$ and an interaction factor $A^{*} B$. This model has the following equation:

$$
Y_{i j k}=\mu+A_{i}+(A B)_{i j}+\varepsilon_{o}
$$

Where: $\mu=$ the parameter of mean population or general mean (grand mean); $A i=$ the parameter of the effect of the $\mathrm{i}$ level of the FA factor; $\mathrm{Bj}=$ the parameter of the effect of the $\mathrm{i}$ level of the FB factor; $(B) i j=$ the parameters of the effect of the interaction factor (ij), with terms of $\Sigma \mathrm{ii} 0$ and $\Sigma \mathrm{j},(\mathrm{B}) \mathrm{ij} 0$.

This test aims to find out the differences in the consequences caused by the manipulations of different independent variables (Jayanti, 2018). This test indicates that each combination of manipulations will produce different consequences. Then, it generally indicates that the combination of variables of degree of religiosity, self-regulation, prevention focus, future orientation, financial knowledge (low and high) will result in the different purchase intention to sharia insurance. 
The population of this study was all students of Esa Unggul University, Citra Raya Tangerang, Indonesia. The consideration is that the research population of all Esa Unggul University of Citra Raya students is quite numerous and heterogeneous. Thus, the authors take a sample of $\mathrm{S} 1$ students using purposive sampling method which means the sample is chosen based on certain criteria. Determination of these criteria includes: embracing Islam, having the same average age, having the same level of education to obtain homogeneous data and represent the population. The respondents are 120 undergraduate students at Esa Unggul University. The respondents are Muslim, aged 18-24 years, and have a minimum education level of high school.

\section{RESULTS OF STUDY}

Determination of the average score or median split of the religiosity, purchase intention, and the focus prevention variables aims to divide the groups in cells from the respondents under research. The median split determination is obtained from 120 data which the value of each variable needs to be known. Religiosity, purchase intention and prevention focus variables are tabulated and the median split is calculated using statistical software. After obtaining the median split scores from the religiosity and prevention focus variables, respondents are categorized as high religiosity (higher than median split) with number 1 and low religiosity (lower than median split) with number 2 . Besides, in the prevention focus variable, the respondents are included in the perception group of high prevention focus (higher than median split) with number 1 and low prevention focus (lower than median split) with number 2.

From the 120 research respondents, there are 61 respondents who have high religiosity and 59 respondents who have low religiosity. Moreover, 61 respondents have high prevention focus and 59 respondents have low prevention focus; as shown in the following table:

Table 1 - The Statistics of Median Split

\begin{tabular}{|c|c|c|c|}
\hline $\mathrm{n} / \mathrm{n}$ & Rel_Code & PF_Code & Intention \\
\hline N Valid & 120 & 120 & 120 \\
\hline N Missing & 0 & 0 & 0 \\
\hline Median & 0.355 & 0.0516 & 0.0498 \\
\hline
\end{tabular}

Source: test results on data analysis tools.

Table 2 - Between Subject Factors

\begin{tabular}{|c|c|c|c|}
\hline \multicolumn{2}{|c|}{ Value Label } & $\mathrm{N}$ \\
\hline \multirow{2}{*}{ Median of Religiosity } & 1.00 & High & 61 \\
\cline { 2 - 4 } & 2.00 & Low & 59 \\
\hline \multirow{2}{*}{ Median of Prevention Focus } & 1.00 & High & 61 \\
\cline { 2 - 4 } & 2.00 & Low & 59 \\
\hline
\end{tabular}

Source: test results on data analysis tools.

Analysis of Research Results on Religiosity and Prevention Focus Variables on Purchase Intention to Long-Term Investment in Sharia Insurance Using Cell Means (Hypothesis 1 and Hypothesis 2 Testing):

$\mathrm{H} 1$ : higher religiosity has higher purchase intention to long-term investment in sharia insurance;

H2a: for low prevention focus group, high religiosity group has higher purchase intention to long-term investment in sharia insurance compared to low religiosity group;

$\mathrm{H} 2 \mathrm{~b}$ : for low religiosity group, high prevention focus group has higher purchase intention to long-term investment in sharia insurance compared to low prevention focus group;

H2c: for high prevention focus group, high religiosity group has higher purchase intention to long-term investment in sharia insurance compared to low religiosity group. 


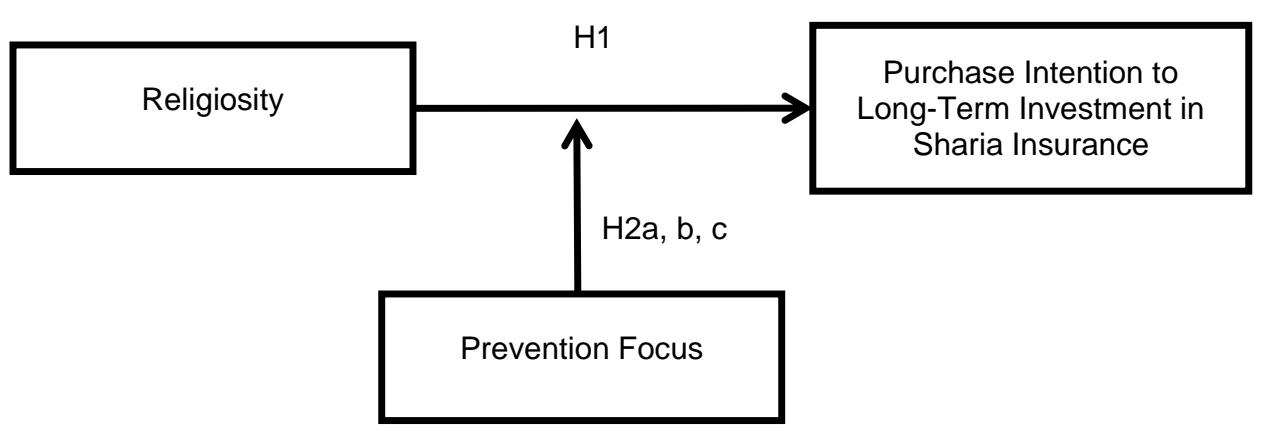

Figure 1 - Research Hypotheses H1 and H2a, b, c

The basic of decision making:

1. If the Sig. value $<0.05, \mathrm{H} 1$ is accepted;

2. If the Sig. value $>0.05, \mathrm{H} 1$ is rejected.

In this research, to test hypotheses 1 and 2, design $A(A B)$ is applied. Thus, in general, the regression equation for this test is as follows:

$$
\text { Yijk }=\mu+\text { RELi }+(\text { REL_PF }) i j+\varepsilon
$$

Prerequisite: $\Sigma i \mathrm{REL}+0 \& \Sigma \mathrm{j}\left(\mathrm{REL} \_\mathrm{PF}\right) \mathrm{ij}=0$, for all $\mathrm{i}$

Where: Yijk = Purchase intention to long-term investment in sharia insurance; $\mu=$ Constanta; RELi = Religiosity; REL_PFij = The interaction between religiosity and prevention focus; $\varepsilon i j k=$ Error.

Table 3 - Parameter Test of Between-Subjects Effects

Dependent Variable: Purchase Intention.

\begin{tabular}{|c|c|c|c|}
\hline Source & df & F & Sig. \\
\hline Corrected Model & 3 & 11.051 & 0.000 \\
\hline Intercept & 1 & 0.082 & 0.775 \\
\hline Religiosity_Code & 1 & 33.146 & 0.000 \\
\hline PF_Code & 1 & 0.010 & 0.920 \\
\hline Religiosity_Code * PF_Code & 1 & 0.007 & 0.935 \\
\hline Error & 116 & & \\
\hline Total & 120 & & \\
\hline Corrected Total & 119 & & \\
\hline
\end{tabular}

Source: test results on SPSS 23 data analysis tools that were reprocessed (2018).

Table 4 - The Results of $\beta 1, \beta 2$, and $\beta 3$

\begin{tabular}{|c|c|}
\hline$\beta$ & Description \\
\hline$\beta 1$ & $\begin{array}{l}\text { For low prevention focus group, high religiosity group has higher purchase intention to long-term investment } \\
\text { in sharia insurance compared to low religiosity group. } \\
\text { The intercept calculation table shows that there is a difference between }[R E L=1][P F=2] \text { and }[R E L=2][P F \\
=2] \text { on purchase intention to long-term investment in sharia insurance that results } \beta 1 \text {. The significant level of } \\
\beta 1 \text { is } 0.000<0.05 \text { so that } \beta 1 \text { is significant. }\end{array}$ \\
\hline$\beta 2$ & $\begin{array}{l}\text { For low religiosity group, high prevention focus group has higher purchase intention to long-term investment } \\
\text { in sharia insurance compared to low prevention focus group. } \\
\text { The intercept calculation table shows that there is a difference between }[R E L=2][P F=1] \text { and }[R E L=2] \\
\text { [PF }=2] \text { on purchase intention to long-term investment in sharia insurance that results } \beta 2 \text {. The significant } \\
\text { level of } \beta 2 \text { is } 0.4945>0.05 \text { so that } \beta 2 \text { is not significant. }\end{array}$ \\
\hline$\beta 3$ & $\begin{array}{l}\text { For high prevention focus group, high religiosity group has higher purchase intention to long-term investment } \\
\text { in sharia insurance compared to low religiosity group. } \\
\text { The intercept calculation table shows that there is a difference between }[P F=1][R E L=1] \text { and }[P F=1][R E L= \\
2] \text { on purchase intention to long-term investment in sharia insurance that results } \beta 3 \text {. The significant level of } \\
\beta 3 \text { is } 0.4675>0.05 \text { so that } \beta 3 \text { is not significant. }\end{array}$ \\
\hline
\end{tabular}

Source: test results on SPSS 23 data analysis tools that were reprocessed (2018). 
The results of this test indicate that the variables to be studied have an effect on purchase intention. The hypothesis testing uses F-test statistics on the line "Rel_Code" with $F 0=33.146$ (Sig. 0,000) and free degree of 1/116. That indicates the Sig. value $0.000<0.05$ which concludes that $\mathrm{H} 1$ supports the proposed hypothesis. It shows that religiosity affects purchase intention to long-term investment in sharia insurance.

Determination of the average score or median split of the religiosity, purchase intention, and the future orientation variables aims to divide the groups in cells from the respondents under research. The median split determination is obtained from 120 data which the value of each variable needs to be known. Religiosity, purchase intention and future orientation variables are tabulated and the median split is calculated using statistical software. After obtaining the median split scores from the religiosity and future orientation variables, respondents are categorized as high religiosity (higher than median split) with number 1 and low religiosity (lower than median split) with number 2 . Besides, in the future orientation variable, the respondents are included in the perception group of high future orientation (higher than median split) with number 1 and low future orientation with number 2.

From the 120 research respondents, there are 61 respondents who have high religiosity and 59 respondents who have low religiosity. Moreover, 61 respondents have high future orientation and 59 respondents have low future orientation; as shown in the table 5:

Table 5 - The Statistics of Median Split

\begin{tabular}{|c|c|c|c|}
\hline $\mathrm{n} / \mathrm{n}$ & Rel_Code & FO_Code & Intention \\
\hline N Valid & 120 & 120 & 120 \\
\hline N Missing & 0 & 0 & 0 \\
\hline Median & 0.355 & 0.127 & 0.049 \\
\hline
\end{tabular}

Source: test results on data analysis tools.

Table 6 - Between Subject Factors

\begin{tabular}{|c|c|c|c|}
\hline \multicolumn{2}{|c|}{ Value Label } & N \\
\hline \multirow{2}{*}{ Religiosity_Code } & 1.00 & High & 63 \\
\cline { 2 - 4 } & 2.00 & Low & 57 \\
\hline \multirow{2}{*}{ FO_Code } & 1.00 & High & 61 \\
\cline { 2 - 4 } & 2.00 & Low & 59 \\
\hline
\end{tabular}

Source: test results on data analysis tools.

Analysis of Research Results on Religiosity and Future Orientation Variables on Purchase Intention to Long-Term Investment in Sharia Insurance Using Cell Means (Hypothesis 3 Testing):

H3a: for low future orientation group, high religiosity group has higher purchase intention to long-term investment in sharia insurance compared to low religiosity group;

$\mathrm{H} 3 \mathrm{~b}$ : for low religiosity group, high future orientation group has higher purchase intention to long-term investment in sharia insurance compared to low future orientation group;

H3c: for high future orientation group, high religiosity group has higher purchase intention to long-term investment in sharia insurance compared to low religiosity group.

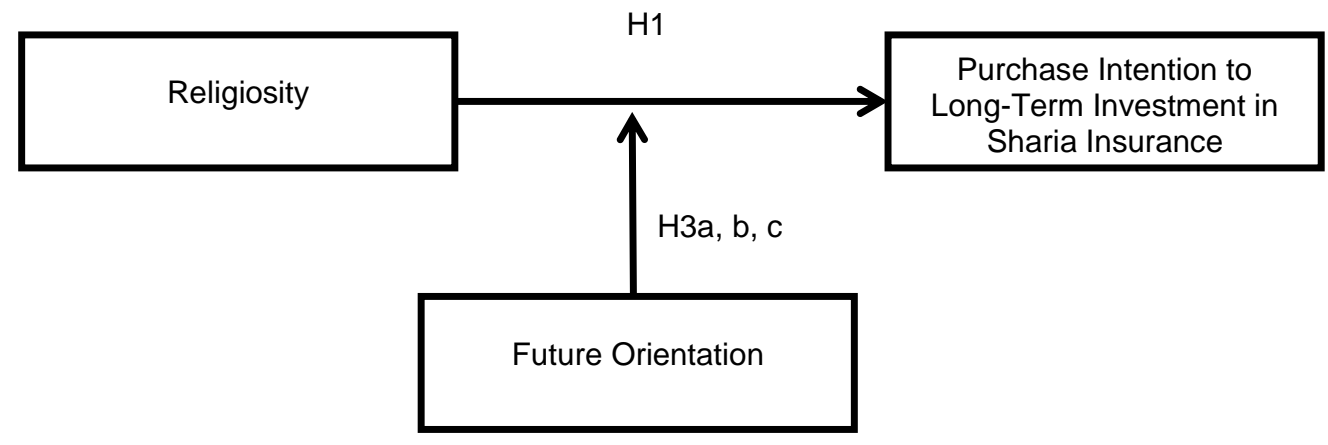

Figure 2 - Research Hypotheses $\mathrm{H} 3 \mathrm{a}, \mathrm{H} 3 \mathrm{~b}$, and $\mathrm{H} 3 \mathrm{c}$ 
The basic of decision making:

1. If the Sig. value $<0.05, \mathrm{H} 1$ is accepted;

2. If the Sig. value $>0.05, \mathrm{H} 1$ is rejected.

In this research, to test hypotheses 3 , design $A(A B)$ is applied. Thus, in general, the regression equation for this test is as follows:

$$
\text { Yijk }=\mu+R E L i+(\text { RELFO }) i j+\varepsilon
$$

Prerequisite: $\Sigma i \mathrm{REL}+0 \& \Sigma \mathrm{j}(\mathrm{RELFO}) \mathrm{ij}=0$, for all $\mathrm{i}$

Where: Yijk = Purchase intention to long-term investment in sharia insurance; $\mu=$ Constanta; $\mathrm{RELi}=$ Religiosity; RELFOij = The interaction between religiosity and future orientation; $\varepsilon i j k=$ Error.

Table 7 - The Results of $\beta 1, \beta 2$ and $\beta 3$

\begin{tabular}{|l|l|}
\hline$B$ & \multicolumn{1}{|c|}{ Description } \\
\hline$\beta 1$ & $\begin{array}{l}\text { For low future orientation group, high religiosity group has higher purchase intention to long-term investment } \\
\text { in sharia insurance compared to low religiosity group. } \\
\text { The intercept calculation table shows that there is a difference between }[F O=2][R E L=1] \text { and }[F O=2] \\
{[R E L=2] \text { on purchase intention to long-term investment in sharia insurance that results } \beta 1 . \text { The significant }} \\
\text { level of } \beta 1 \text { is } 0.006<0.05 \text { so that } \beta 1 \text { is significant. }\end{array}$ \\
\hline$\beta 2$ & $\begin{array}{l}\text { For low religiosity group, high future orientation group has higher purchase intention to long-term investment } \\
\text { in sharia insurance compared to low future orientation group. } \\
\text { The intercept calculation table shows that there is a difference between }[R E L=2][F O=1] \text { and }[F O=2] \\
{[R E L=2] \text { on purchase intention to long-term investment in sharia insurance that results } \beta 2 . \text { The significant }} \\
\text { level of } \beta 2 \text { is } 0.012>0.05 \text { so that } \beta 2 \text { is significant. }\end{array}$ \\
\hline$\beta 3$ & $\begin{array}{l}\text { For high future orientation group, high religiosity group has higher purchase intention to long-term } \\
\text { investment in sharia insurance compared to low religiosity group. } \\
\text { The intercept calculation table shows that there is a difference between }[F O=1][R E L=1] \text { and }[F O=1] \\
{[R E L=2] \text { on purchase intention to long-term investment in sharia insurance that results } \beta 3 . \text { The significant }} \\
\text { level of } \beta 3 \text { is } 0.027<0.05 \text { so that } \beta 3 \text { is significant. }\end{array}$ \\
\hline
\end{tabular}

Source: test results on data analysis tools.

Table 8 - The Statistics of Median Split

Dependent Variable: Purchase Intention.

\begin{tabular}{|c|c|c|c|}
\hline $\mathrm{n} / \mathrm{n}$ & Rel_Code & FK_Code & Purchase Intention \\
\hline N Valid & 120 & 120 & 120 \\
\hline N Missing & 0 & 0 & 0 \\
\hline Median & 0.355 & 5.5 & 0.049 \\
\hline
\end{tabular}

Source: test results on data analysis tools.

Table 9 - Between Subject Factors

Dependent Variable: Purchase Intention.

\begin{tabular}{|c|c|c|c|}
\hline \multicolumn{2}{|c|}{ Value label } & N \\
\hline \multirow{2}{*}{ Religiosity_Code } & 1.00 & High & 63 \\
\cline { 2 - 4 } & 2.00 & Low & 57 \\
\hline \multirow{2}{*}{ FK_Code } & 1.00 & High & 60 \\
\cline { 2 - 4 } & 2.00 & Low & 60 \\
\hline
\end{tabular}

Source: test results on data analysis tools of SPSS 23.

Determination of the average score or median split of the religiosity, purchase intention, and the financial knowledge variables aims to divide the groups in cells from the respondents under research. The median split determination is obtained from 120 data which the value of each variable needs to be known. Religiosity, purchase intention and financial knowledge variables are tabulated and the median split is calculated using statistical software. After obtaining the median split scores from the religiosity and financial knowledge variables, respondents are categorized as high religiosity (higher than median split) with number 1 and 
low religiosity (lower than median split) with number 2. Besides, in the financial knowledge variable, the respondents are included in the perception group of high financial knowledge (higher than median split) with number 1 and low financial knowledge (lower than median split) with number 2.

From the 120 research respondents, there are 63 respondents who have high religiosity and 57 respondents who have low religiosity. Moreover, 60 respondents have high financial knowledge and 60 respondents have low financial knowledge.

Analysis of Research Results on Religiosity and Financial Knowledge Variables on Purchase Intention to Long-Term Investment in Sharia Insurance Using Cell Means (Hypothesis 4 Testing):

H4a: for low financial knowledge group, high religiosity group has higher purchase intention to long-term investment in sharia insurance compared to low religiosity group;

H4b: for low religiosity group, high financial knowledge group has higher purchase intention to long-term investment in sharia insurance compared to low financial knowledge group;

H4c: for high financial knowledge group, high religiosity group has higher purchase intention to long-term investment in sharia insurance compared to low religiosity group.

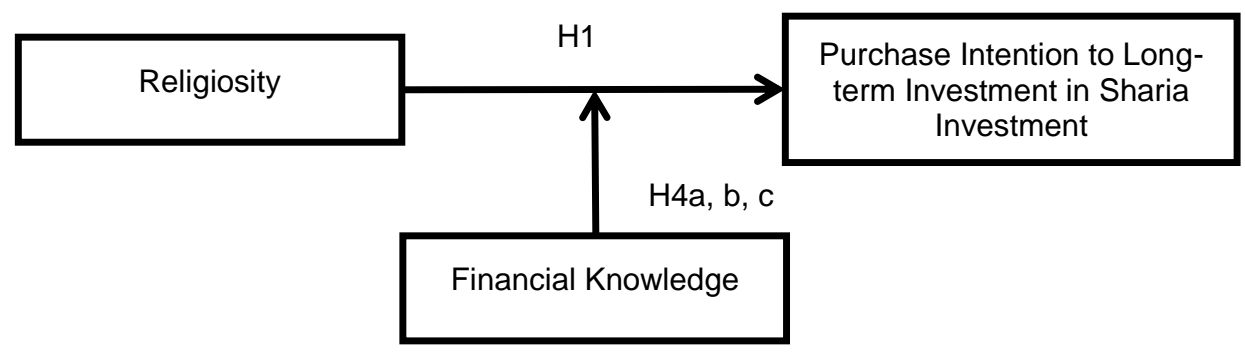

Figure 3 - Research Hypotheses H4a, H4b, and H4c

The basic of decision making:

1. If the Sig. value $<0.05, \mathrm{H} 1$ is accepted;

2. If the Sig. value $>0.05, \mathrm{H} 1$ is rejected.

In this research, to test hypotheses 4 , design $A(A B)$ is applied. Thus, in general, the regression equation for this test is as follows:

$$
\text { Yijk }=\mu+R E L i+(R E L F K) i j+\varepsilon
$$

Prerequisite: $\Sigma i \mathrm{REL}+0 \& \Sigma \mathrm{j}(\mathrm{RELFK}) \mathrm{ij}=0$, for all $\mathrm{i}$

Where: Yijk = Purchase intention to long-term investment in sharia insurance; $\mu=$ Constanta; $\mathrm{RELi}=$ Religiosity; RELFOij = The interaction between religiosity and financial knowledge; $\varepsilon i j k=$ Error.

Table 10 - The Result of $\beta 1, \beta 2$ and $\beta 3$

\begin{tabular}{|c|c|}
\hline$B$ & Description \\
\hline$\beta 1$ & $\begin{array}{l}\text { For low financial orientation group, high religiosity group has higher purchase intention to long-term investment in } \\
\text { sharia insurance compared to low religiosity group. } \\
\text { The intercept calculation table shows that there is a difference between }[F K=2][R E L=1] \text { and }[F K=2][R E L=2] \\
\text { on purchase intention to long-term investment in sharia insurance that results } \beta 1 \text {. The significant level of } \beta 1 \text { is } \\
0.000<0.05 \text { so that } \beta 1 \text { is significant. }\end{array}$ \\
\hline$\beta 2$ & $\begin{array}{l}\text { For low religiosity group, high financial knowledge group has higher purchase intention to long-term investment in } \\
\text { sharia insurance compared to low financial knowledge group. } \\
\text { The intercept calculation table shows that there is a difference between }[R E L=2][F K=1] \text { and }[R E L=2][F K=2] \\
\text { on purchase intention to long-term investment in sharia insurance that results } \beta 2 \text {. The significant level of } \beta 2 \text { is } \\
0.333>0.05 \text { so that } \beta 2 \text { is not significant. }\end{array}$ \\
\hline$\beta 3$ & $\begin{array}{l}\text { For high financial knowledge group, high religiosity group has higher purchase intention to long-term investment in } \\
\text { sharia insurance compared to low religiosity group. The intercept calculation table shows that there is a difference } \\
\text { between }[R E L=1][F K=1] \text { and }[R E L=2][F K=2] \text { on purchase intention to long-term investment in sharia } \\
\text { insurance that results } \beta 3 \text {. The significant level of } \beta 3 \text { is } 0.355>0.05 \text { so that } \beta 2 \text { is not significant. }\end{array}$ \\
\hline
\end{tabular}

Source: test results on data analysis tools. 


\section{DISCUSSION OF RESULTS}

Higher Religiosity Has Higher Purchase Intention to Long-Term Investment in Sharia Insurance. Based on the testing results of hypothesis 1, it is found that the results of the analysis supported the hypothesis $\mathrm{H} 1$; i.e. with the Sig. value $0.000<0.05$ where higher religiosity will increase purchase intention to long-term investment in sharia insurance. The research findings are in line with the findings of previous research conducted by Newas et al (2016) who stated that religiosity is significantly related to Muslim customers' views on Islamic law and their attitude towards sharia financial products; however, it does not support purchase intention to sharia insurance. Previous research found that customers are more concerned with high profits and low service costs offered by conventional funds (Zaher and Kabir Hassan, 2001). Nurlette et al's findings (2018) have also strengthened our findings in which religiosity has significantly supported opening gold savings. These research findings identify that religiosity significantly affects individuals directly or through moderation variable on purchase to long-term investment in sharia insurance.

For Low Prevention Focus Group, High Religiosity Group Has Higher Purchase Intention to Long-Term Investment in Sharia Insurance Compared to Low Religiosity Group. The test results on the hypothesis $\mathrm{H} 2 \mathrm{a}$ found that the analysis results support the hypothesis; with the Sig. value $0.000<0.05$. The interpretation of the results of this hypothesis is that an individual with low level of self-regulation, prevention focus and security will still have the intention or purchase intention to long-term investment in sharia insurance if the individual has a high level of religiosity. The results are in accordance with the research conducted by Hawlett et al (2008) that self-regulation has a significant effect on the possibility of contributing to pension funds. This is also in line with the findings of a research conducted by Manurung et al (2017) which in the SRF Prevention group, respondents who have high literacy have high investment intention compared to those who have low literacy. It has been proven to support the hypothesis with the $\beta 1$ value $=-0.228$ and the Sig. value $=0.04(<0.05)$ that has met the data significance criteria.

For Low Religiosity Group, High Prevention Focus Group Has Higher Purchase Intention to Long-Term Investment in Sharia Insurance Compared to Low Prevention Focus Group. The test results on the $\mathrm{H} 2 \mathrm{~b}$ hypothesis found that the analysis results do not support the hypothesis; with the Sig. value $0.475<0.05$. Husin and Rahman (2015) examined the effect of religiosity on individual behavior to participate in the family tafakul with insignificant results. However, our findings are no in line with the research conducted by Manurung et al., (2017) that respondents with low financial literacy and SRF prevention have a higher investment intention than respondents who have SRF promotion with $\beta 2=-0.263$ and Sig. value $=0.02(<0.05)$ that meets the data significance criteria.

For High Prevention Focus Group, High Religiosity Group Has Higher Purchase Intention to Long-Term Investment in Sharia Insurance Compared to Low Religiosity Group. The test results on the H2c hypothesis found that the analysis results do not support the hypothesis; with the Sig. value 0.430>0.05. Our research findings are not in accordance with the findings of a research conducted by Manurung et al (2017) that respondents who have high financial literacy and SRF prevention tend to have a greater investment intention than SRF Promotion; with $\beta 3=-0.233$ and the Sig. value $=0.021 \quad(<0.05)$ that meets the data significance criteria.

For Low Future Orientation Group, High Religiosity Group Has Higher Purchase Intention to Long-Term Investment in Sharia Insurance Compared to Low Religiosity Group. The test results on the $\mathrm{H} 3 \mathrm{a}$ hypothesis found that the analysis results support the hypothesis with the Sig. value $0.006<0.05$. The findings on $\mathrm{H} 3 \mathrm{a}$ are also in line with previous research that showed correlation between future orientation and dependent variables (Newaz et al, 2008). In addition, Newaz's research also reported that customers with high level of CFC or Consideration Future Consequences are more likely to participate in retirement plans. Jacobs-Lawson and Hershey (2005) have examined the role of future time perspective towards saving behavior with the result that future time perspective significantly supports retirement saving. Based on these findings, we can see that future orientation has a very 
important role in purchase intention to long-term investment in sharia insurance; moreover, this variable has moderated the religiosity variable. It is very interesting to investigate further because high future orientation and low future orientation has been proven to significantly affect purchase intention to long-term investment in sharia insurance as stated in the hypotheses $\mathrm{H} 3 \mathrm{a}, \mathrm{H} 3 \mathrm{~b}$, and $\mathrm{H} 3 \mathrm{c}$.

For Low Religiosity Group, High Future Orientation Group Has Higher Purchase Intention to Long-Term Investment in Sharia Insurance Compared to Low Future Orientation Group. With the Sig. value $0.012<0.05$, the findings in $\mathrm{H} 3 \mathrm{~b}$ are also in line with previous research that showed a correlation between future orientation and dependent variables (Newaz et al, 2008). In addition, their research reported that consumers with high levels of CFC or Consideration Future Consequences will be more likely to participate in retirement plans. Jacobs-Lawson and Hershey (2005) have examined the role of future time perspective towards saving behavior with the result that future time perspective significantly supports retirement saving.

For High Future Orientation Group, High Religiosity Group Has Higher Purchase Intention to Long-Term Investment in Sharia Insurance Compared to Low Religiosity Group. With the Sig. value $0.027<0.05$, the findings in $\mathrm{H} 3 \mathrm{~b}$ are also in line with previous research that showed a correlation between future orientation and dependent variables (Newaz et al, 2008). In addition, their research reported that consumers with high levels of CFC or Consideration Future Consequences will be more likely to participate in retirement plans. Jacobs-Lawson and Hershey (2005) have examined the role of future time perspective towards saving behavior with the result that future time perspective significantly supports retirement saving.

For Low Financial Knowledge Group, High Religiosity Group Has Higher Purchase Intention to Long-Term Investment in Sharia Insurance Compared to Low Religiosity Group. The test results in the hypothesis $\mathrm{H} 4 \mathrm{a}$ found that the analysis results support the hypothesis with the Sig. value $0.000<0.05$. This finding shows that financial knowledge variables have an important role in purchase intention to long-term investment in sharia insurance when moderated by religiosity variable. In addition, this finding is also consistent with the findings of Newaz et al (2008) which support the importance of healthy finance for a better life in the future. Our findings have supported the need for financial knowledge in making decisions. This finding is also supported by Jacobs-Lawson and Hershey (2005) that financial knowledge combined with future time perspective and saving behavior, with the results of the degree of financial knowledge, significantly supports retirement saving. Similarly, with a high degree of future time perspective that has significantly affected risk tolerance. In age subsamples, subjective or objective financial knowledge in older age groups-related to longterm and short-term financial behavior-is stronger than subjective or objective financial knowledge in the younger age group. In the older age group, objective financial knowledge is more closely related to long-term financial behavior than one of the two other measures of financial literacy.

For Low Religiosity Group, High Financial Knowledge Group Has Higher Purchase Intention to Long-Term Investment in Sharia Insurance Compared to Low Financial Knowledge Group. The test results on the H4b hypothesis have not supported the hypothesis with the Sig. value $0.333>0.05$. The interpretation of the results of the hypothesis is that religiosity still has a very important role in purchase intention to sharia insurance. Our interpretation to this finding is that customers who have high financial knowledge will tend to choose non-sharia insurance products. This finding is also almost the same as the findings from $\mathrm{H} 2 \mathrm{~b}$ that the $\mathrm{H} 4 \mathrm{~b}$ group is not a consumer that can be prioritized in marketing sharia products. Our findings have reinforced the need for financial knowledge in making decisions. This is contrary to the findings of Jacobs-Lawson and Hershey (2005) that the role of financial knowledge combined with future time perspective and saving behavior-with the results of the degree of financial knowledge-significantly supports retirement saving. Similarly, high future time perspective degree significantly affects risk tolerance.

For High Financial Knowledge Group, High Religiosity Group Has Higher Purchase Intention to Long-Term Investment in Sharia Insurance Compared to Low Religiosity Group. 
The test results on the $\mathrm{H} 4 \mathrm{C}$ hypothesis support the hypothesis with the Sig. value $0.355>0.05$. Our guess is that groups with high financial knowledge and high religiosity will tend to increase purchase intention. However, this is just beyond our expectations. This is contrary to the findings of Jacobs-Lawson and Hershey (2005) that the role of financial knowledge combined with future time perspective and saving behavior-with the results of the degree of financial knowledge-significantly supports retirement saving. Similarly, a high degree of future time perspective significantly affects risk tolerance.

\section{CONCLUSION}

Our research has examined the effect of religiosity on the purchase intention to longterm insurance investments that are moderated by self-regulation, future orientation and financial knowledge. This research applies a non-hierarchical method or cell means method using between subjects 2x2 and applies the Univariate General Linear Model (GLM) procedure. Our first research finding is that religiosity (REL) has significantly affected the purchase intention to long-term investment in sharia insurance (intention). Thus, $\mathrm{H} 1$ is proven to support the hypothesis. The second conclusion is that religiosity which is moderated by the prevention focus is proven to increase the purchase intention to long-term investment in sharia insurance or $\mathrm{H} 2 \mathrm{a}$ has been proven to support the hypothesis. However, religiosity which is moderated by a high prevention focus has not supported the hypothesis. So, $\mathrm{H} 2 \mathrm{~b}$ and $\mathrm{H} 2 \mathrm{c}$ do not support the hypothesis.

The third conclusion is that religiosity which is moderated by the future orientation has shown very significant results. Thus, the hypotheses $\mathrm{H} 3 \mathrm{a}, \mathrm{H} 3 \mathrm{~b}$, and $\mathrm{H} 3 \mathrm{c}$ have been proven to support the hypothesis. This finding is very important for insurance business actors and the government since awareness of the importance of preparing for the future has begun among undergraduate students. Therefore, it can be concluded that future orientation is very effective in affecting the purchase intention to long-term investment in sharia insurance. This is what must be immediately followed up and made a top priority in designing marketing strategies. The final conclusion is that religiosity which is moderated by financial knowledge generally has been proven to affect the purchase intention to long-term investment in sharia insurance so that $\mathrm{H} 4 \mathrm{a}$ has supported the research hypothesis. However, religiosity which is moderated by high financial knowledge has not supported the hypothesis; so, $\mathrm{H} 4 \mathrm{~b}$ and $\mathrm{H} 4 \mathrm{c}$ are not proven. The thing that needs to be followed up is the need for a religious approach so that this sharia insurance product can be marketed more optimally.

\section{LIMITATION OF THE RESEARCH}

The limitations of this research have several weaknesses. The first limitation is that this research only takes samples of undergraduate students of Esa Unggul Citra Raya University for all majors while the population at Esa Unggul Citra Raya University is undergraduate and graduate students. The second limitation is that the sample is limited to one university. Finally, the third limitation is that the religiosity variable only measures Muslim respondents.

\section{REFERENCES}

1. Gunawan, I. (2013). Metode penelitian kualitatif. Jakarta: Bumi Aksara.

2. Howlett, E., Kees, J., \& Kemp, E. (2008). The role of self-regulation, future orientation, and financial knowledge in long-term financial decisions. Journal of Consumer Affairs, 42(2), 223-242.

3. Jacobs-Lawson, J. M., \& Hershey, D. A. (2005). Influence of future time perspective, financial knowledge, and financial risk tolerance on retirement saving behaviors. Financial Services Review-Greenwich, 14(4), 331.

4. Jayanti, E. D. (2018). Strategi Perencanaan Peningkatan Penyaluran Kredit and Perkembangan Bprs Di Jawa Timur Yang Terdaftar Pada Bank Indonesia (Doctoral dissertation, Universitas Muhammadiyah Gresik). 
5. Manurung, H., Bramani, R., Ricky, I., \& Darmanto, D. (2017). Pengaruh literasi keuangan terhadap intensi berinvestasi dengan moderasi self regulatory focus. Indonesian Business Review, 1(1).

6. Newaz, F. T., Fam, K. S., \& Sharma, R. R. (2016). Muslim religiosity and purchase intention of different categories of Islamic financial products. Journal of Financial Services Marketing, 21(2), 141-152.

7. Nugraha, J. (2014). Pengantar Analisis Data Kategorik: Metode and Aplikasi Menggunakan Program R. Deepublish.

8. Nurlette, U. A., Sobari, A., \& Kosim, A. M. (2018). Analisis Strategi Pemasaran Produk Gadai Emas (Rahn) Dalam Meningkatkan Pendapatan Bank (Studi Kasus Bank BJB Syariah Cabang Bogor). Al-Infaq: Jurnal Ekonomi Islam, 5(2), 201-242.

9. Pramesti, G. (2007). Aplikasi SPSS 15.0 dalam Model Linier Statistika. Jakarta: Elex Media Komputindo.

10. Rahardjy, P., \& Manurung, M. (2008). Pengantar ilmu ekonomi:(mikroekonomi \& makroekonomi). Lembaga Penerbit Fakultas Ekonomi Univ. Indonesia.

11. Ramadhani, H. (2015). Prospek and Tantangan Perkembangan Asuransi Syariah di Indonesia. Al-Tijary: Jurnal Ekonomi and Bisnis Islam, 1(1), 57-66.

12. Sukmadinata, N. S. (2007). Metode penelitian. Bandung: PT Remaja Rosda Karya.

13. Zaher, T. S., \& Kabir Hassan, M. (2001). A comparative literature survey of Islamic finance and banking. Financial Markets, Institutions \& Instruments, 10(4), 155-199. 